\title{
PEMBERDAYAAN PETANI PADI MENGGUNAKAN PUPUK ORGANIK UNTUK MENINGKATKAN PRODUKTIVITAS HASIL PANEN DI MASA PANDEMI
}

\author{
Ngabdur Rohman Sidiq \\ Pengembangan Masyarakat Islam (PMI) Fakultas Dakwah INSURI Ponorogo Jawa Timur \\ Indonesia \\ D455615@gmail.com
}

\begin{abstract}
Indonesia is famous for being an agrarian country, a country where most of the people work in agriculture are still not able to develop the productivity of rice yields. For this reason, it is necessary to empower farmers to increase crop productivity, especially those in Tegalombo Village, Kauman District. The method used in this research is a qualitative research method using a descriptive approach which is carried out by observation, interviews and documentation. This study resulted that farmer empowerment carried out in Tegalombo Village, Kauman District can be said to have been better in terms of Where the production which increases the productivity of the rice harvest is getting better and increasing, this is because the knowledge and skills of farmers in farming also increase. The main driving factor for success in increasing crop productivity in Tegalombo Village, Kauman District is the running of the program with support from the Farmer's Group as well as the socialization of organic fertilizer and assistance in the use of liquid organic fertilizer for maximum yields. The obstacles come from the problem of the low quality of human resources, capital and erratic weather, cheap harvests, and increasingly scarce and expensive fertilizers. This requires a synergy between farmers, the community and the government to jointly support farmer empowerment programs to increase the productivity of rice yields.
\end{abstract}

Keywords :Empowerment, Productivity, Improving Rice Harvest.

\begin{abstract}
Abstrak
Indonesia terkenal dengan Negara agraris ,Negara yang sebagian besar masyarakatnya bekerja dibidang pertanian masih belum mampu mengembangkan produktivitas hasil panen padi. Untuk itu perlu dilakukannya pemberdayaan petani guna meningkatkan produktivitas hasil panen, khususnya yang berada di Desa Tegalombo Kecamatan Kauman . Metode yang digunakan dalam penelitian ini adalah metode penelitian kualitatif dengan menggunakan pendekatan deskriptif yang dilakukan dengan observasi, wawancara dan dokumentasi. Penelitian ini menghasilkan bahwa pemberdayaan petani yang dilakukan di Desa Tegalombo,Kecamatan Kauman dapat dikatakan sudah lebih baik dalam. Dimana produksi yang peningkatan produktivitas panen padi menjadi lebih baik dan meningkat, ini dikarenakan pengetahuan dan keterampilan petani dalam bercocok tanam juga meningkat. Faktor pendorong utama keberhasilan dalam meningkatkan produktivitas hasil panen di Desa Tegalombo,Kecamatan Kauman adalah berjalannya program dengan adanya dukungan dari Kelompok Tani serta adanya sosialisasi pupuk organik dan pendampingan dalam penggunaan pupuk organik cair agar hasil panen maksimal. Hambatannya datang dari masalah rendahnya kualitas sumber daya manusia, modal dan cuaca yang tidak menentu,hasil panen yang murah,pupuk semakin langka dan mahal. Hal ini diperlukan adanya sinergi diantara petani, masyarakat serta pemerintah untuk secara bersama-sama mendukung program pemberdayaan petani untuk meningkatkan produktivitas hasil panen padi.
\end{abstract}

Kata Kunci: Pemberdayaan, Produktivitas, Peningkatan Panen Padi 


\section{A. Pendahuluan}

Pertanian merupakan salah satu aset terbesar di negara Indonesia. Pertanian erat kaitannya dengan pengolahan lahan, sehingga Indonesia dapat disebut sebagai negara agraris. Negara agraris merupakan negara yang memiliki sebagian wilayah berupa pertanian atau pengolahan tanah. Tentunya hal tersebut harus didukung dengan berbagai pengembangan dan inovasi agar pemanfaatan tanah untuk pertanian tetap lestari dan terjaga, serta menghasilkan produk yang unggul dan dapat memenuhi kebutuhan pangan rakyat Indonesia. Pertanian di Indonesia tersebar diberbagai daerah, salah satu tempat yang memiliki potensi pertanian di Kabupaten Ponorogo adalah Desa Tegalombo, Kecamatan Kauman.

Desa Tegalombo merupakan salah satu desa pertanian yang dapat dikatakan memiliki potensi sumber daya alam yang sangat kaya.Terutama pertanian padi. Bila dilihat dari potensi sumber daya alam sesungguhnya Desa Tegalombo memiliki prospek yang cukup baik sebagai penghasil padi yang cukup menjanjikan apabila masyarakat desa sepenuhnya menyadari bahwa bidang pertanian dapat dijadikan asset untuk masa depan mereka. Akan tetapi, terdapat beberapa hambatan-hambatan, seperti SDM yang rendah, sikap mental masyarakat yang belum menyadari bahwa lahan pertanian dapat dijadikan sebagai mata pencaharian utama, aspek kewirausahaan belum tumbuh secara nyata, kurangnya modal dan juga kelompok tani yang belum berjalan dengan maksimal, sehingga produktivitas hasil panen yang masih rendah.

Kelompok tani di desa dianggap sebagai salah satu pendukung dalam mengakses bebagai informasi tentang pertanian. Maka dari itu perlunya dilakukan pemberdayaan terhadap masyarakat agar mampu meningkatkan produktivits hasil pertanian . Pemberdayaan dianggap penting dalam meningkatkan taraf hidup, tingkat kesejahteraan serta pengembangan ekonomi masyarakat.Melihat hal tersebut, sesuai denganarahan KPM yang dilakukan dengan metode ABCD,dengan cara mengembangkan aset.Yaitu dengan cara mengembangkan pertanian dengan melakukan pemberdayaan kepada para petani. Terlebih di era pandemi ini pupuk semakin mahal,buruh semakin berkurang, dan cuaca yang kurang mendukung, sehingga produktivitas panen padi menurun.Bermula dari permasalahan tersebut, maka peneliti memiliki inisiatif untuk mengembangkan pupuk organik cair berbasis mikroorganisme yang ramah lingkungan untuk meningkatkan produktivitas panen padi petani dengan hasil yang maksimal. Hal tersebut dilakukan dengan pemberdayaan petani.

Pemberdayaan petani yang ada di Desa Tegalombo yaitu melalui pendampingan dan berpartisipasi serta penyuluhan. Penyuluhan dilakukan dengan memberikan informasi tentang trobosan baru serta cara bercocok tanam dengan cara yang lebih baik kepada Para 
Petani .Penyuluhan tersebut ditujukan untuk meningkatkan kemampuan serta keterampilan masyarakat petani dalam menjalankan usaha taninya agar mendapatkan hasil yang lebih banyak, lebih baik serta beragam.

Hasil yang lebih banyak degan modal yang lebih sedikit dapat menunjang terwujudnya peningkatan hasil produktivitas panen padi pada masa pandemi ini. Penyuluhan dilakukan dengan memberikan informasi tentang teknologi baru, cara bercocok tanam ,menggunakan pestisida yang baik dan mensosialisasikan pentingnnya penggunaan pupuk organik cair . Penyuluhan atau pendampingan ini disampaikan kepada petani setempat oleh Mahasiswa yang melakukan KPM-DR. Penyuluhan atau pendampingan tersebut ditujukan untuk meningkatkan kemampuan serta keterampilan petani dalam menjalankan usaha taninya agar mendapakan hasil yang lebih banyak, lebih baik serta beragam. Hasil yang lebih banyak dan modal yang lebih sedikit, dengan kualitas yang lebih baik tersebutlah yang nantinya dapat menunjang terwujudnya suatu ketahanan pangan dan kemakmuran masyarakat yang merata, serta mempunyai daya jual yang tinggi.

Usaha peningkatan produktivitas Padi dapat dilakukan dengan cara penggunaan bibit unggul, pemupukan dengan takaran yang tepat dan pengairan yang cukup. Pemupukan menjadi salah satu faktor seperti limbah pertanian maupun industri yang pemanfaatannya dapat meningkatkan produktivitas tanah. Mikroorganisme lokal (MOL) merupakan salah satu contoh pupuk organik cair yang terbentuk dari bahan-bahan alami yang disukaitanamansebagaimediahidupdanberkembangnyamikroorganisme(DirektoratPengelolaa nLahan,2007). MOL juga berfungsi sebagaidekomposer atau aktivator dan tambahan nutrisi bagi tumbuhan yang sengaja dikembangkan dari mikroorganisme yang bisa diperbanyak yang berfungsi sebagai "starter" dalam pembuatan kompos, pupuk organik cair, dan pakan ternak (Arum et al, 2019). Mikroorganisme memiliki peranan dalam masa pertumbuhan vegetatif tanaman dan tanaman toleran terhadap penyakit. Kadar asam fenolat penting dalam usaha peningkatan yang tinggi membantu peningkatan ion-ion produksi selain pemilihan bibit unggul.Pupuk organik mempunyai fungsi yang sangat penting yaitu untuk menggemburkan lapisan tanah permukaan, meningkatkan populasi jasad renik, mempertinggi daya serap dan daya simpan air sehingga kesuburan tanah dapat ditingkatkan sedangkan pupuk organik lebih praktis dalam pemakaian karena disesuaikan dengan perhitungan hasil penyelidikan akan unsur hara yang tersedia dalam kandungan tanah,meringankan biaya pengangkutan, mudah didapat serta dapat disimpan lama dan konsentrasi akan zat-zat makanan wajib pertumbuhan dan perkembangan tanaman ternyata tinggi (Mulyani, 2019). 
Pemberdayaan petani padi dengan penyuluhan, pendampingan dan pengembangan dalam pengolahan lahan dan proses penanaman padi sampai panen melalui pemberdayaan dalam menggunakan pupuk organik cair sebagai pupuk alternatif diharapkan mampu meningkatkan produktifitas hasil panen padi di Desa Tegalombo, Kecamatan Kauman,Kabupaten Ponorogo.

\section{B. Metode Pendampingan}

Pelaksanaan pengabdian dan penelitian ini menggunakan pendekatan Asset Based Community Development (ABCD), yaitu mengembangkan pemanfaatan aset dan potensi yang ada disekitar dan dimiliki oleh masyarakat. Pendekatan berbasis asset memberikan cara pandang baru yang lebih holisti, kreatif dan inovatif dalam melihat realitas, seperti melihat gelas setengah penuh mengapresiasikan apa yang bekerja dengan baik dimasa lampau dan menggunkan apa yang kita miliki untuk mendapatkan apa yang kita inginkan(Christopher Dureau,2013).Pendekatan inilebih memilih cara pandang bahwasanya dalam masyarakat pasti memiliki sesuatu yang dapat dimanfaatkan dan dikembangkan, karena selalu ada manfaat yang dapat diambil dari setiap ciptaan Tuhan.Aset merupakan suatu hal yang dapat digunakan atau dimanfaatkan guna memenuhi kebutuhan dan bernilai kekayaan.

Pendekatan berbasis aset membantu komunitas melihat kenyataan mereka dan kemungkinan perubahan secara berbeda. Mempromosikan perubahan fokus pada apa yang ingin mereka capai dan membantu mereka menemukan cara baru dan kreatif untuk mewujudkan visi mereka. Masyaraat merupakan asset yang paling berharga bagi keberadaan desa. Sebagaimana petani adalah asset yang sangat berharga dimana petani ini yang akan menyokong kesedian pangan di Kelurahan Keniten khususnya dan di Ponorogo umumnya.

Metode ABCD memiliki beberapa langkah, antara lain :

1) Inkulturasi (Perkenalan) Marty Seligman menyatakan bahwa apabila masyarakat menitik beratkan pada bahaya di sekitar mereka, hal ini dapat membantu masyarakat tumbuh lebih aman. Konsekuensi dari menghindari bahaya adalah menyelamatkan hidup.Maka cukup alamiah apabila masyarakat/komunitas mitra pada tahap awal menekankan penghindaran daripada bersikap positif untuk menjaga keselamatan mereka dan orangorang yang mereka sayangi. Oleh karena itu, tahap inkulturasi menjadi sangat penting dalam kesuksesan sebuah program pengembangan masyarakat. Tahap ini biasanya dilakukan pada minggu pertama kegiatan.Inkulturasi menjadi sebuah keharusan untuk 
mengurangi sikap penghindaran dari komunitas mitra sehingga kepercayaan masyarakat dapat terbangun dengan baik.

2) Discovery (Mengungkapkan Informasi) Dalam sebuah rencana aksi pengembangan masyarakat yang sangat penting untuk dilakukan. Namun demikian, perencanaan aksi tidaklah dapat dilakukan tanpa didahului oleh identifikasi informasi-informasi penting yang menjadi landasan sebuah perencanaan. Proses pengungkapan informasi inilah yang kita sebut sebagai discovery. Discovery dapat dilakukan setelah inkulturasi selesai.

3) Design (Mengetahui Aset dan Mengidentifikasi Peluang) Pada tahap ini, tujuan penggolongan dan mobilisasi aset adalah untuk langsung membentuk jalan menuju pencapaian visi atau gambaran masa depan. Setelah diidentifkasi, sudah selayaknya komunitas mendapatkan informasi mengenai aset yang dimiliki. Dengan demikian, komunitas akan menyadari kekuatan positif yang mungkin belum mereka sadari keberadaannya di desa mereka. Untuk itu, kegiatan sosialisasi aset menjadi sebuah langkah yang diharapkan mampu membawa semangat democratic governance. Prinsip transparansi informasi mengenai keberadaan aset desa dan akuntabilitas penggunaan aset desa tersebut selama ini dapat dipupuk dengan komunikasi yang intensif antara warga dan pimpinan disana. Tahap ini bisa dilakukan setelah discovery selesai sehingga data temuan siap disajikan.

4) Define(mendukung keterlaksanaan program kerja)Bila komunitas sudah bisa membayangkan dunianya dengan cara berbeda dan berbagi visi masa depannya, akan ada berbagai jenis kegiatan dengan cakupan yang luas yang dilakukan oleh kelompok dan anggota denganmenggunakan aset mereka untuk mencapai beragam bagiandari mimpi mereka. Masyarakat sudah bisa menentukanbahwa program inilah yang akan menjadi prioritas utama.

5) Refelection (Refleksi) Pendekatan berbasis aset juga membutuhkan studi data dasa (baseline), monitoring perkembangan dan kinerja (outcome). Tetapi bila suatu program perubahan menggunakan pendekatan berbasis aset, maka yang dicari bukanlah bagaimana setengah gelas yang kosong akan diisi, tetapi bagaimana setengah gelas yang penuh dimobilisasi. Pendekatan berbasis aset bertanya tentang seberapa besar anggota organisasi atau komunitas mampu menemukenali dan memobilisasi secara produktif aset mereka mendekati tujuan bersama.

Dalam pendampingan masyarakat dengan metode $\mathrm{ABCD}$, ada beberapa prinsip yang harusdiperhatikan. Adapun prinsipnya adalah sebagai berikut; (Nadhir Salahuddin,2015). 
1) Setengah Terisi lebih Berarti (Half Full Half Empty) adalah satu modal utama dalam program pengabdian terhadap masyarakat berbasis aset adalah merubah cara pandang komunitas terhadap dirinya. Tidak hanya terpaku pada kekurangan dan masalah yang dimiliki. Tetapi memberikan perhatian kepada apa yang dipunyai dan apa yang dapat dilakukan.

2) Semua Punya Potensi (Nobody Has Nothing) Dalam konteks ABCD, prinsip ini dikenal dengan istilah "Nobody has nothing". Setiap manusia terlahir dengan kelebihan masing-masing. Tidak ada yang tidak memiliki potensi, walau hanya sekedar kemampuan untuk tersenyum dan memasak air. Semua berpotensi dan semua bisa berkontribusi.

3) Partisipasi (Participation) Partisipasi adalah suatu keterlibatan mental dan emosi seseorang kepada pencapaian tujuan dan ikut bertanggung jawab di dalamnya. Partisipasi berarti peran yang sangat urgen terhadap petani untuk meningkatkan ketahanan pangan pada masa pandemi dalam bentuk pernyataan maupun dalam bentuk kegiatan dengan memberi masukanpikiran, tenaga, waktu, keahlian, serta ikut memanfaatkan hasil -hasilnya.

4) Kemitraan (Partnership) Partnership merupakan salah satu prinsip utama dalam pendekatanpengembangan masyarakat berbasis aset(Asset Based Community Development).Partnership merupakan modal utama yang sangat dibutuhkan dalam memaksimalkan posisi dan peran masyarakat dalam pengembangan yang dilakukan. Hal itu dimaksudkan sebagai bentuk pembangunan dimana yang menjadi motor dan penggerak utamanya adalah masyarakat itu sendiri (community driven development).

5) Penyimpangan Positif (Positive Deviance), Positive Deviance atau (PD) secara harfiah berarti penyimpangan positif. Secara terminologi positive deviance (PD) adalah sebuah pendekatan terhadap perubahan perilaku individu dan sosial yang didasarkan pada realitas bahwa dalam setiap masyarakat meskipun bisa jadi tidak banyak terdapat orang-orang yang mempraktekkan strategi atau perilaku sukses yang tidak umum, yang memungkinkan mereka untuk mencari solusi yang lebih baik atas masalah yang dihadapi daripada rekan-rekan mereka.

6) Berawal Dari Masyarakat (Endogenous).Endogenous dalam konteks pembangunan memiliki beberapa konsep inti yang menjadi prinsip dalam pendekatan pengembangan dan pemberdayaan komunitasmasyarakat berbasis asset-kekuatan. 
7) Menuju Sumber Energi (Heliotropic) Energi dalam pengembangan bisa beragam. Di antaranya adalah mimpi besar yang dimiliki oleh komunitas, proses pengembangan yang apresiatif, atau bisa juga keberpihakan anggota komunitas yang penuh totalitas dalam pelaksanaan program.

\section{Hasil dan Pembahasan}

Di masa pandemi banyak sekali probelematika diantaranya dalam bidang ekonomi. Ekonomi yang saat ini gencar-gencarnya yaitu masalah merosotnya harga padi yang menurun drastis. Oleh karena itu petani harus mempunyai trobobasan baru dalam mengolah lahan pertanian agar hasil padi yang ditanam dapat meningkat dari hasil yang sebelumnya. Mengingat keluh kesah para petani di musim era pandemi saat ini harga padi tidak sesuai dari modal yang dikeluarkan oleh petani .Maka dari itu banyak petani yang mengeluh karena kebutuhan pangan tidak tercukupi. Oleh karena itu perlu adanya koordinasi atau kelompok tani dalam menyejahterakan para petani dalam mengaplikasikan pupuk organik agar hasil panen meningkat.Melihat kondisi tanah pada saat ini petani sering menggunakan pupuk yang berbahan kimia yang mengakibatkan lahan pertanian kekurangan zat hara,sehingga tanaman tidak dapat tumbuh subur.

Pupuk organik cair adalah pupuk yang tersedia dalam bentuk cair, POC dapat diartikan sebagai pupuk yang dibuat secara alami melalui proses fermentasi sehingga menghasilkan larutan hasil pembusukan dari sisa tanaman, maupun kotoran hewan atau manusia $^{[1]}$ Bagi sebagian orang pupuk organik cair lebih baik untuk digunakan karena terhindar dari bahan-bahan kimia/sintetis serta dampak yang baik bagi kesehatan. Pupuk organik cair terdiri dari mikroorganisme yang berperan penting dalam membantu pertumbuhan tanaman ( Suryani Kurniawi,dkk, 2020 ).

Pupuk organik cair memiliki kelebihan, antara lain :

1. Biasanya dapat digunakan sebagai pupuk dasar tanaman, yang bersifat release dan memiliki kandungan unsur hara lengkap.

2. Pupuk cair dapat langsung bisa diserap oleh daun untuk fotosintesis.

3. Pengaplikasihan sangat mudah dan tidak membutuhkan biaya yang cukup mahal.

4. Dapat membantu meningkatkan kapasitas tukat katian (KTK)

5. Dapat membantu dalam proses pelapukan bahan mineral

6. Meningkatkan ketersediaan unsur hara 
7. Menjadikan sumber bahan makanan bagi mikroorganisme tanah, seperti bakteri, fungi yang menguntungkan.

8. Meningkatkan pengikatan antar partikel

9. Dapat membantu merevitalisasi daya olah tanah dan mengemburkan media tanah dengan optimal.

Pupuk organik akan menetralisir zat hara pada tanah, dengan adanya pupuk organik maka akar pada tanaman akan sangat kuat dan tanaman akan tumbuh subur,serta meningkatkan hasil panen petani.Untuk meningkatkan efektivitas dalam memberdayakan petani padi dalam penggunaan pupuk organik saya ikut berpartisipasi dalam bercocok tanam dan kegiatan sosial,membantu dalam pembuatan pupuk organik untuk meningkatkan hasil panen.Menurut Parman (2007), nitrogen dalam pupuk organik cair berfungsi untuk menyusun protein yang berfungsi pada metabolisme tanaman yang selanjutnya akan memacu pembelahan dan pemanjangan sel. Semakin tinggi kandungan nitrogen pada bahan organik semakin baik pula bahan tersebut untuk digunakan sebagai pupuk. Unsur Nitrogen dibutuhkan oleh tanaman dalam jumlah yang lebih banyak dari pada unsur hara lainnya, karena sangat berperan dalam aktifitas fotosintesa sehingga berpengaruh pada ertumbuhan dan hasil tanaman (Sulfianti,dkk, 2016).

Dalam kegiatan pengabdian dan penelitian ini, peneliti melakukan pembinaan kepada beberapa petani untuk sebagai realisasi cara pembuatan pupuk organik cair dan penerapan pada tanaman padi. Peserta dalam kegiatan tersebut sangat antusias dalam menyimak materi, hal ini bisa disinyalir bahwa di pandemi ini petani kesulitan dalam memeroleh pupuk, pupuk tergolong mahal, dan cuaca yang sangat kurang mendukung sehingga harus ada media untuk mengatasi hal tersebut.

Setelah melakukan sosialisasi dan pembuatan pupuk organik cair, maka tahap selanjutnya yaitu realisasi penggunaan pupuk organik dalam tanaman padi, realisasi ini dimaksud pemberian pupuk pada tanaman padi bersama petani desa. 


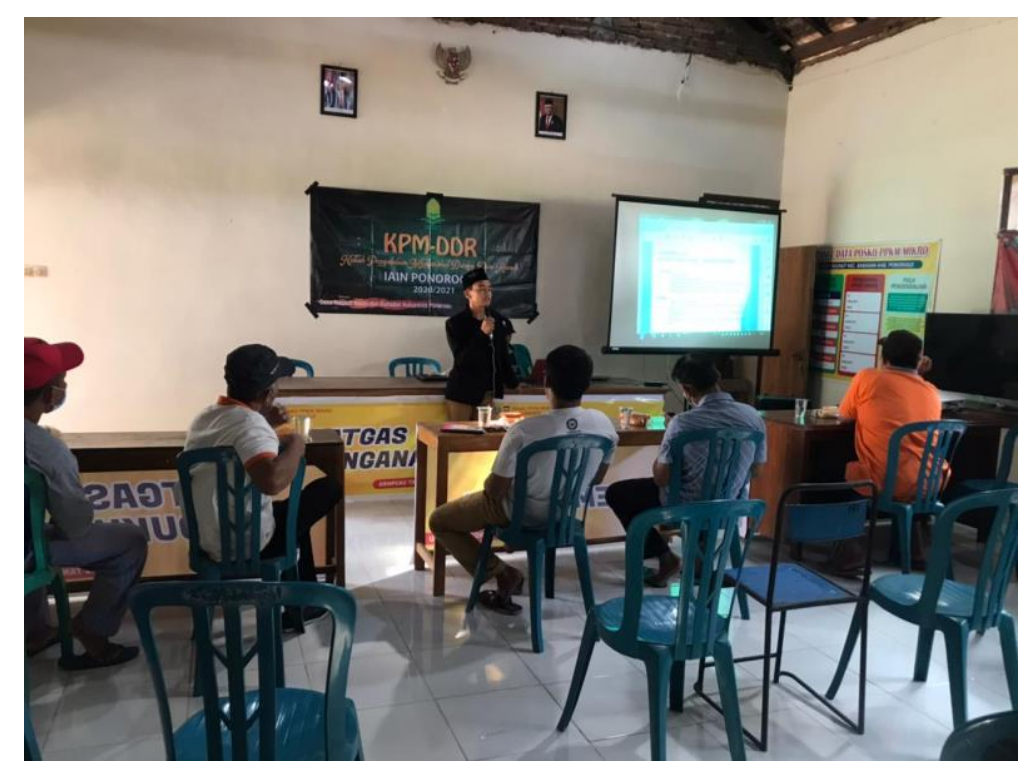

Gambar 1.1

Sosialisasi Pembuatan Pupuk Organik Cair

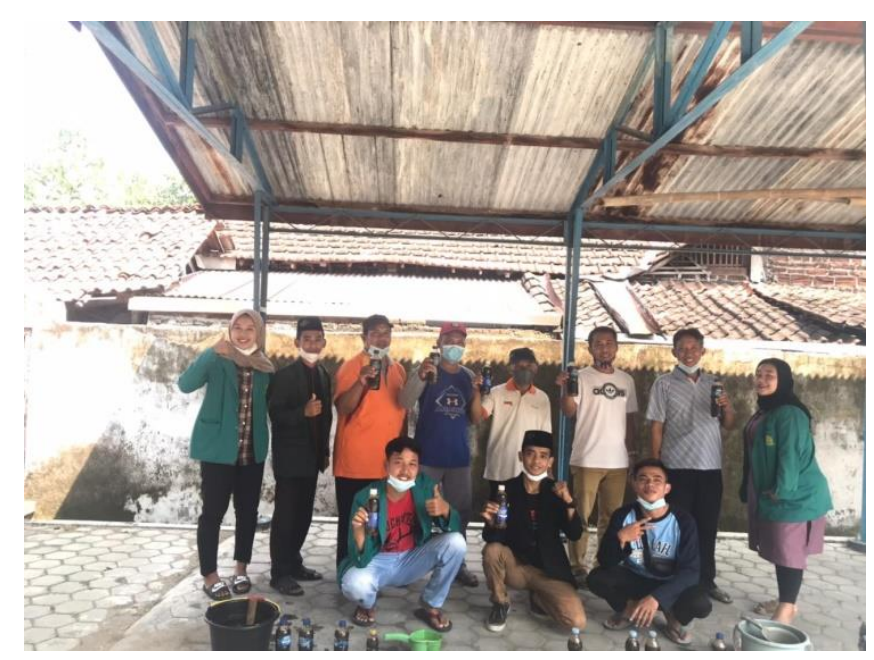

Gambar 1.2

Pembuatan Pupuk Organik Cair

Pupuk organik cair yang dikembangkan peneliti merupakan pupuk yang ramah lingkungan. Berbagai bahan yang digunakan merupakan bahan organik yang ramah lingkungan. Berikut beberapa hal terkait pembuatan dan pengelolaan pupuk organik cair : 


\section{Bahan :}

1) 400 gr urea

2) 400 gr bekatul

3) 0,5 liter tetes

4) Ampela ayam

5) Air 3-4 liter
Alat-alat :
1) Ember
2) Pengaduk Kayu
3) Aqua Botol
4) Gayung
5) Pisau atau Silet

\section{Cara pembuatan}

1) Siapkan air 3-4 liter di dalam ember

2) Masukkan 400 gr urea dan aduk hingga larut

3) Masukkan 400 gr bekatul, dan aduk

4) Masukkan 0,5 liter tetes sambil diaduk hingga larut

5) Masukkan isi ampela dan cacahan ampela

\section{Penggunaan dan manfaat}

1) Masukkan pupuk cair ke dalam botol dan simpan dalam keadaan tertutup selama 7-10 hari. Semprot untuk penggunaan

2) 200ml dapat dicampur 2-3 liter air putih

3) Manfaat : untuk menghilangkan bau limbah, campuran minuman ternak, dan mempercepat pertumbuhan tanaman,serta meningkatkan hasil panen dari panen yang sebelumnya

4) Pupuk ini dapat disemprotkan kepada tanaman setiap 2 minggu sekali dengan cara disemprot sesuai takaran tersebut 
Hasil Pengamatan Panen Padi Tanpa Pupuk Organik Cair ( lahan $840 \mathrm{~m}^{2}$ )

\begin{tabular}{|l|l|}
\hline Waktu & Hasil Panen $(\mathrm{kg})$ \\
\hline Desember 2020 - Februari 2021 & 280 \\
\hline Februari-April 2021 & 280 \\
\hline Mei-juli 2021 & 290 \\
\hline
\end{tabular}

Hasil Pengamatan Panen Padi Menggunakan Pupuk Organik Cair ( lahan $840 \mathrm{~m}^{2}$ )

\begin{tabular}{|l|l|}
\hline Waktu & Hasil Panen $(\mathrm{kg})$ \\
\hline Desember 2020 - Februari 2021 & 360 \\
\hline Februari-April 2021 & 376 \\
\hline Mei-juli 2021 & 376 \\
\hline
\end{tabular}

Dari tabel hasil pengamatan tersebut dapat kita ketahui bahwa perbedaan hasil panen antara lahan yang menggunakan pupuk organik cair lebih banyak daripada lahan yang tidak menggunakan pupuk organik cair. Terbukti pupuk organik cair yang dikembangkan peneliti memiliki dampak nyata dan mampu meningkatkan produktivitas hasil panen padi di Desa Tegalombo. Diharapkan proses dan hasil tersebut dapat terus dikembangkan untuk meningkatkan kesejahteraan petani Desa Tegalombo.

\section{Kesimpulan}

Penelitian ini menghasilkan bahwa pemberdayaan petani yang dilakukan di Desa Tegalombo,Kecamatan Kauman dapat dikatakan sudah lebih baik. Dimana produksi yang peningkatan produktivitas panen padi menjadi lebih baik dan meningkat, ini dikarenakan pengetahuan dan keterampilan petani dalam bercocok tanam juga meningkat. Faktor pendorong utama keberhasilan dalam meningkatkan produktivitas hasil panen di Desa Tegalombo,Kecamatan Kauman adalah berjalannya program dengan adanya dukungan dari Kelompok Tani serta adanya sosialisasi pupuk organik dan pendampingan dalam penggunaan pupuk organik cair agar hasil panen maksimal. Hambatannya datang dari masalah rendahnya kualitas sumber daya manusia, modal dan cuaca yang tidak menentu,hasil panen yang murah,pupuk semakin langka dan mahal. Hal ini diperlukan adanya sinergi diantara petani, masyarakat serta pemerintah untuk secara bersama-sama mendukung program pemberdayaan petani untuk meningkatkan produktivitas hasil panen padi.Dari hasil penelitian tersebut dapat kita ketahui bahwa perbedaan hasil panen antara lahan yang menggunakan pupuk organik cair lebih banyak daripada lahan yang tidak menggunakan pupuk organik cair. Terbukti pupuk organik cair yang dikembangkan peneliti memiliki 
dampak nyata dan mampu meningkatkan produktivitas hasil panen padi khususnya di Desa Tegalombo. Diharapkan proses dan hasil tersebut dapat terus dikembangkan untuk meningkatkan kesejahteraan petani Desa Tegalombo.

\section{Daftar Pustaka}

Arum, A,Suhastyo, Fanny, T. R. (2019). "Respon Pertumbuhan dan Hasil Sawi Pagoda (Brasssica narinosa) terhadap pemberian MOL daun kelor". Agrotech Research Journal. 3(1):56-60.

Direktorat Pengelolaan Lahan. (2007). "Pedoman Teknis Pengembangan Usaha tani Padi Sawah MetodeSystem of Rice Intencification (SRI)". Jakarta: Direktorat Jenderal Pengelolaan Lahan dan Air Departemen Pertanian.

Dureau, Christopher. "Pembaru Dan Kekuatan Lokal Untuk Pembangunan". TT: Australian Community Development And Civil Society Strengthening Scheme ( ACCESS) Phase II, 2013.

Salahuddin, Nadir. " Panduan KKN ABCD UIN Sunan Ampel Surabaya Aset Based Community-Driven Developmenent (ABCD).” Surabaya: LP2M Uin Sunan Ampel Surabaya, 2015.

Sri Ita Tarigan,Suryani Kurniawi,dkk (2020 ). "Pelatihan Pembuatan Pupuk Organik Cair Berbasis Abstraksi Mikroorganisme Lokal Di Desa Tanau, Kabupaten Sumba Timur” . Sawala: Jurnal pengabdian Masyarakat Pembangunan Sosial, Desa dan Masyarakat, $78-85$

Sulfianti., 2013. "Pengaruh Kondisi dan LamaFermentasi terhadap Kualitas Ekstrak OrganiK Cair yang diaplikasikan padaTanaman Bayam (Amaranthus sp)”. Tesis.Palu : Program Pascasarjana UniversitasTadulako.

Syaifudin, A., L., Mulyani, \& Sulastri, E. (2008). "Pemberdayaan mikroorganisme lokal sebagai upaya peningkatan kemandirian petani”.http://le3n1.blog.uns.ac.id. [29 November 2019]. 